\title{
Microbially-charged electrochemical fuel for energy storage in a redox flow cell
}

\author{
Márcia S.S. Santos ${ }^{\mathrm{a}, \mathrm{b}, \mathrm{c}}$, Luciana Peixoto ${ }^{\mathrm{a}}$, João Azevedo ${ }^{\mathrm{b}, \mathrm{d}}$, Ricardo A.R. Monteiro ${ }^{\mathrm{b}}$, \\ Celia Dias-Ferreira ${ }^{c, e}$, M. Madalena Alves ${ }^{a}$, Adélio Mendes ${ }^{b, *}$ \\ ${ }^{a}$ CEB, Centre of Biological Engineering, University of Minho, Campus de Gualtar, 4710-057, Braga, Portugal \\ ${ }^{\mathrm{b}}$ LEPABE, Laboratory for Process Engineering, Environment, Biotechnology and Energy, Faculty of Engineering of the University of Porto, Rua Dr. Roberto Frias, 4200- \\ 465, Porto, Portugal \\ c CERNAS, Research Centre for Natural Resources, Environment and Society, Coimbra College of Agriculture, Bencanta, 3040-316, Coimbra, Portugal \\ d IFIMUP and IN-Institute of Nanoscience and Nanotechnology, Department of Physics and Astronomy, Faculty of Sciences of the University of Porto, Rua Do Campo \\ Alegre 687, 4169-007, Porto, Portugal \\ ${ }^{\mathrm{e}}$ Universidade Aberta, R. Almirante Barroso, 38-4 Piso, 1000-013, Lisboa, Portugal
}

\section{H I G H L I G H T S}

- Microbially-charged electrochemical fuel were achieved in BES.

- No bias potential was applied for microbially-charged electrochemical fuel.

- Bio-charged negalyte was tested in a 2,6-AQDS . $\|\left[\mathrm{Fe}(\mathrm{CN})_{6}\right]^{4-}$ redox flow cell.

- Coulombic efficiencies ca. $90 \%$ in the RFC with the redox pairs were reached.

\section{A R T I C L E I N F O}

\section{Keywords:}

Bioelectrochemical systems

Redox flow cells

Energy conversion

Bioenergy

Microbially-charged electrochemical fuel
G R A P H I C A L A B S T R A C T

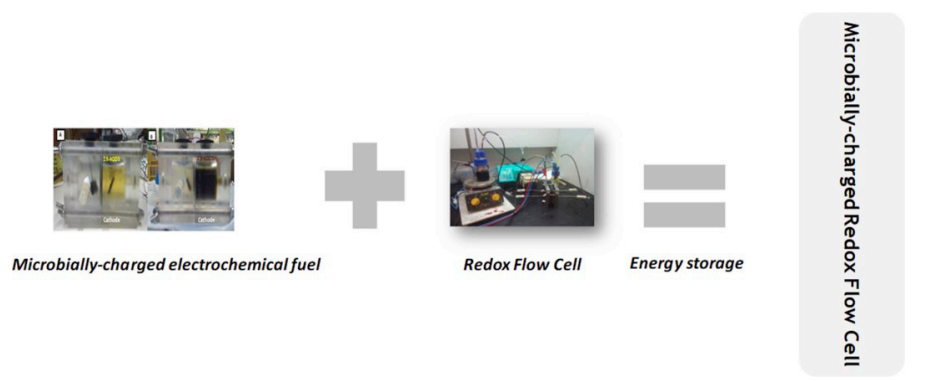

\begin{abstract}
A B S T R A C T
A Bioelectrochemical System (BES) is used for charging an electrochemical fuel to be used in a Redox Flow Cell (RFC), demonstrating the first proof of concept of a microbially-charged electrochemical fuel. Geobacter sulfurreducens, electroactive bacteria, was used to charge anthraquinone-2,6-disulfonate (2,6-AQDS) producing current densities of $c a .200-500 \mathrm{~mA} \mathrm{~m}^{-2}$ and maximum power densities of $c a .33 \mathrm{~mW} \mathrm{~m}^{-2}$. The microbially-charged electrochemical fuel and potassium ferricyanide, $\mathrm{K}_{3}\left[\mathrm{Fe}(\mathrm{CN})_{6}\right]$ were introduced in a RFC producing a potential difference of $0.62 \mathrm{~V}$, with a $\mathrm{ca}$. $80 \%$ energy conversion efficiency. The use of a BES for charging the posilyte of a $\mathrm{RFC}$ is now envisioned. The bio-conversion of waste biomass energy into electrochemical fuels (microbiallycharged electrochemical fuel for negalyte and posilyte) for later use in a RFC to produce electricity is a promising approach of converting biomass into storable and easy to use energy.
\end{abstract}

\footnotetext{
* Corresponding author.

E-mail address: mendes@fe.up.pt (A. Mendes).
} 


\section{Introduction}

For making renewable energy, such as solar electricity, dispatchable, it is necessary to use energy storage systems [1]. Despite the advantage of conventional batteries and supercapacitors to store and making available energy with a very high round-trip-efficiency, their energy density is still quite low when compared with the high-energy density displayed by fuels. Redox Flow Cells (RFCs) are an electrochemical storage technology where energy is stored in soluble redox pairs $[1,2]$. The soluble redox pairs introduced in external tanks and pumped into the cell, where the redox reactions take place, is the feature that allows setting power and energy capacity independently; power is determined by the stack size and energy by the volume of the electrolytes. Also, the design of RFCs offers fast diffusion of both redox pairs and charge carriers in the electrolyte [3].

The best known RFCs technologies use aqueous solutions of vanadium and sulphuric acid and are used for stationary applications competing favorably with lithium based batteries [4,5]. Ion metals such as vanadium [6,7], chromium [8], iron [9], zinc [10] and other simple inorganic compounds and metal complexes $[10,11]$ have been studied for RFCs; recently introduced organic redox species are a step forward for use in RFC since they can be produced from renewable sources, are stable and show reversible redox reaction [12], good redox potential windows, high flexibility, tunability and solubilities [13]. Among the different choices for organic RFCs redox couples, quinones have recently been proposed as promising for their low cost [12-15]. These compounds exhibit reversible redox reactions: quinones are reduced to the respective hydroquinones forms [16], and these redox reactions are explored to charge and discharge RFCs [11], with inorganic compounds such as bromide [17] or ferricyanide [18] as redox couples. Also, the non-aqueous solvents are more expensive than water and may raise safety and environmental issues [3].

Energy efficiencies of $90 \%$ were reported for vanadium RFCs [19, 20], lithium RFCs [21,22] or organic RFCs [23-25]. In the all-vanadium RFCs, power density of $9000000 \mathrm{~mW} \mathrm{~m}^{-2}$ was reported [26] while for quinone-based RFCs this value is ca. $1000000 \mathrm{~mW} \mathrm{~m}^{-2}$ [25,27] (Fig. 1). The use of quinones in organic RFCs is safer than the use of metals, like vanadium, that exhibit some toxicity $[28,29]$. Some studies reported the use of anthraquinones in RFCs [30]; the first organic-inorganic aqueous
RFC used 9,10-anthraquinone-2,7-disulfonic acid and bromine $\left(\mathrm{Br}_{2} / \mathrm{HBr}\right)$ as redox pairs [24]. This quinone was also used in the development of a solar redox flow cell [31,32]; this device converts the solar energy in storable electrochemical energy, easily converted in electrical energy. 9,10-anthraquinone-2,6-disulfonic acid (2,6-AQDS) and 4,5-dihydroxybenzene-1,3-disulfonic acid were studied as redox species in RFC with bromine [25,33]; 2,6-AQDS coupled with potassium ferricyanide, a fast redox couple can be used to operate a RFC.

Bioelectrochemical systems (BESs) are systems capable of converting chemical energy into electricity or hydrogen/chemical products [34, 35]. A basic configuration of a BES is the Microbial Fuel Cell (MFC) that generates electrons through the conversion of organic biodegradable compounds by electroactive bacteria [36]. When these electrons migrate from the anode to the cathode in a MFC, there is a direct production of electricity $[37,38]$. In a broader sense, BESs include many more configurations and have been demonstrated in several applications and configurations, such as in energy production coupled to wastewater treatment $[39,40]$, synthesis of hydrogen in Microbial Electrolysis Cells $[41,42]$, synthesis of methane $[43,44]$ or others biochemical products (e.g. 1,3-propanediol) in Microbial Electrosynthesis Cells [45] or water treatment such as in Microbial Desalination Cells [46]. BESs are expected to play an important role in small/on site applications such as biosensors and automatisms [47,48], in situ bioremediation [49] and wastewater treatment [50,51]. BESs are also promising as the core technology in bioeletrorefineries including biofuels production [52].

One of the critical limitations of BESs is their low cell potential output, which is not suitable for practical applications [53]. During the initial development of BESs there was an exponential increase in power densities. This trend ended around 2007 when power densities tended to stabilize around $1000 \mathrm{~mW} \mathrm{~m}^{-2}$ [54-67] (Fig. 1). This tendency was due to the initial focus on the optimization of configurations and electrode materials, which, when optimized, led to the search for new applications for this technology to the detriment of improvements in the generated power. Nowadays, BES has been coupled with others electrochemical devices, such as photo-driven coupling systems [68], or energy-harvesting circuits and BESs coupled-power management systems [53] to improve cell potential without reversal.

BESs can also be used for charging redox pairs, which can be fed in a RFC for efficiently converting the stored electrochemical energy

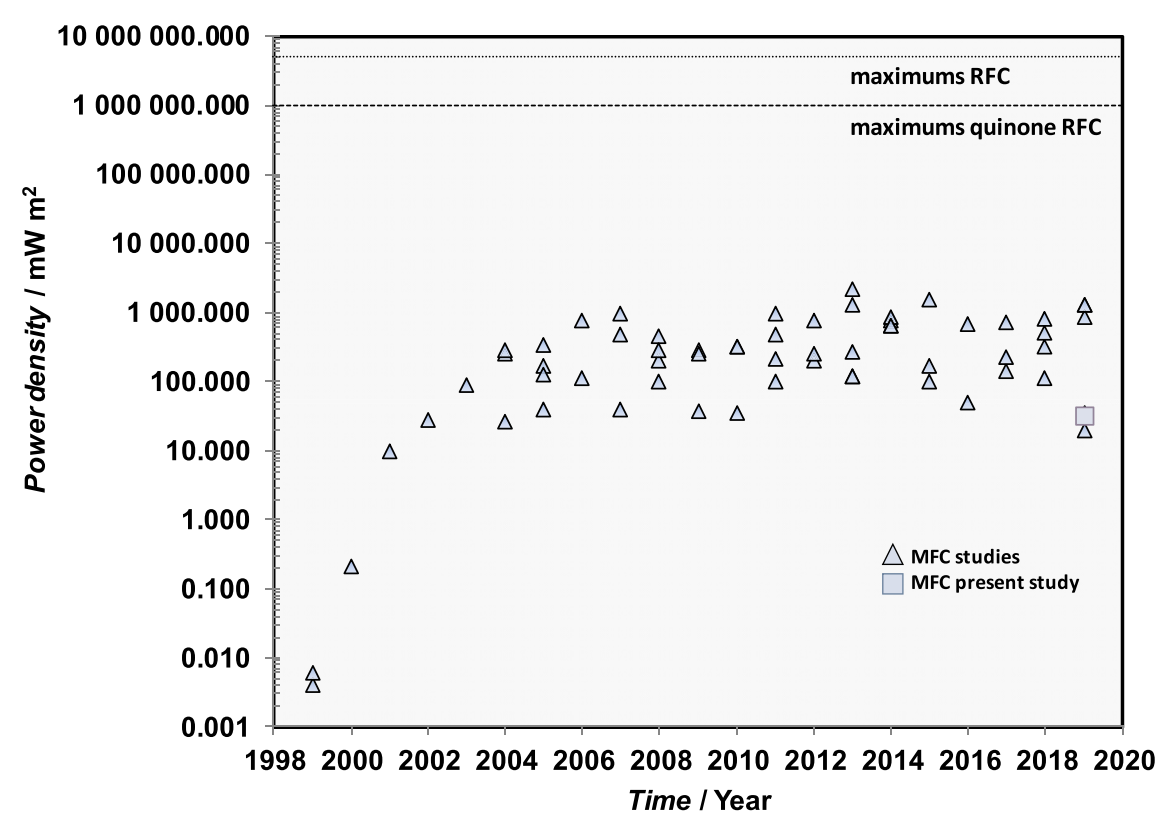

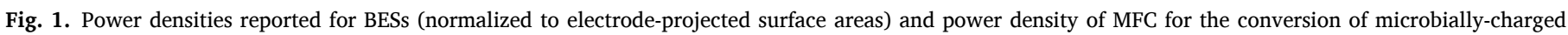
electrochemical fuel (MFC of the present study) (adapted from Ref. [69]). 
(microbially-charged electrochemical fuel) into electricity. Several redox pairs suitable for working in alkaline or in acid media and exhibiting quasi continuous redox potentials and potential differences are available [52]. This allows choosing the best suited redox pair and operating conditions for a given microorganism that permits the electrochemical conversion of these redox pairs in BESs and their use in RFCs without bias potential applied. This flexibility is not observed in Microbial Electrolysis Cells, where the electrode potentials and potential difference are set from the beginning [54]. The bioelectrochemical conversion of redox pairs in BES for electrical energy storage purposes has not been explored, so far.

In this work 2,6-AQDS was converted in a MFC forming a microbially-charged electrochemical fuel which, together with electrochemically charged posilyte potassium ferricyanide (III) $\left(\mathrm{K}_{3} \mathrm{Fe}(\mathrm{CN})_{6}\right)$, were supplied to a RFC for producing electricity. This work also demonstrates the feasibility of coupling a BES with a RFC for making a Microbial Redox Flow Cell (Fig. 2). This new approach is a proof of concept of bioelectrochemical energy storage for easily producing electricity in a RFC.

\section{Experimental}

\subsection{Chemicals and materials}

The chemicals used in this study were of analytical grade from Sigma Aldrich; the water used was purified using a Milli-Q ${ }^{\circledR}$ Integral Water Purification system. The 9,10-anthraquinone-2,6-disulfonic acid (2,6AQDS; $\mathrm{C}_{14} \mathrm{H}_{6} \mathrm{Na}_{2} \mathrm{O}_{8} \mathrm{~S}_{2}$ ) was used as purchased. The proton exchange membrane Nafion ${ }^{\mathrm{TM}} \mathrm{NM} 117$ and carbon felt electrodes were acquired from Quintech.

\subsection{Bacteria's strains and culture conditions}

Geobacter sulfurreducens (DSM 12127) was cultivated at $30^{\circ} \mathrm{C}$ and $150 \mathrm{rpm}$ until exponential growth phase in the Geobacter medium 826 (adapted from DSMZ). This medium was prepared with
$1.50 \mathrm{~g} \mathrm{~L}^{-1} \mathrm{NH}_{4} \mathrm{Cl}, 0.60 \mathrm{~g} \mathrm{~L}^{-1} \mathrm{Na}_{2} \mathrm{HPO}_{4}, 0.10 \mathrm{gL}^{-1} \mathrm{KCl}, 10 \mathrm{~mL} \mathrm{~L}^{-1}$ of the trace element solution and $1 \mathrm{mLL}^{-1}$ selenite-tungstate solution. The trace element and the selenite-tungstate solutions were from stock solutions prepared and reserved in sterile glass bottles at $4{ }^{\circ} \mathrm{C}$. The trace element solution contains: $1.50 \mathrm{~g} \mathrm{~L}^{-1}$ nitrilotriacetic acid, $3.00 \mathrm{~g} \mathrm{~L}^{-1}$ $\mathrm{MgSO}_{4} \cdot 7 \mathrm{H}_{2} \mathrm{O}, 0.50 \mathrm{gL}^{-1} \mathrm{MnSO}_{4} \cdot 7 \mathrm{H}_{2} \mathrm{O}, 1.00 \mathrm{gL}^{-1} \mathrm{NaCl}, 0.10 \mathrm{gL}^{-1}$ $\mathrm{FeSO}_{4} \cdot 7 \mathrm{H}_{2} \mathrm{O}, 0.18 \mathrm{~g} \mathrm{~L}^{-1} \mathrm{CoSO}_{4} \cdot 7 \mathrm{H}_{2} \mathrm{O}, 0.10 \mathrm{gL}^{-1} \mathrm{CaCl} \cdot 2 \mathrm{H}_{2} \mathrm{O}, 0.18 \mathrm{gL}^{-1}$ $\mathrm{ZnSO}_{4} \cdot 7 \mathrm{H}_{2} \mathrm{O}, 0.01 \mathrm{~g} \mathrm{~L}^{-1} \mathrm{CuSO}_{4} \cdot 5 \mathrm{H}_{2} \mathrm{O}, 0.02 \mathrm{~g} \mathrm{~L}^{-1} \mathrm{KAI}\left(\mathrm{SO}_{4}\right)_{2} \cdot 12 \mathrm{H}_{2} \mathrm{O}$, $0.01 \mathrm{~g} \mathrm{~L}^{-1} \mathrm{H}_{3} \mathrm{BO}_{3}, 0.01 \mathrm{gL}^{-1} \mathrm{Na}_{2} \mathrm{MoO}_{4} \cdot 2 \mathrm{H}_{2} \mathrm{O}, 0.03 \mathrm{~g} \mathrm{~L}^{-1} \mathrm{NiCl}_{2} \cdot 6 \mathrm{H}_{2} \mathrm{O}$, $0.0003 \mathrm{~g} \mathrm{~L}^{-1} \mathrm{Na}_{2} \mathrm{SeO}_{3} \cdot 5 \mathrm{H}_{2} \mathrm{O}$. The selenite-tungstate solution was prepared with $0.50 \mathrm{~g} \mathrm{~L}^{-1} \mathrm{NaOH}, 0.003 \mathrm{~g} \mathrm{~L}^{-1} \mathrm{Na}_{2} \mathrm{SeO}_{3} \cdot 5 \mathrm{H}_{2} \mathrm{O}$ and $0.004 \mathrm{~g} \mathrm{~L}^{-1}$ $\mathrm{Na}_{2} \mathrm{WO}_{4} \cdot 2 \mathrm{H}_{2} \mathrm{O}$. The medium was boiled and cooled down with ice until room temperature while deaerated with a stream of $\mathrm{N}_{2}: \mathrm{CO}_{2}(80 \%: 20 \%)$. After cooling down, $2.5 \mathrm{~g} \mathrm{~L}^{-1}$ of $\mathrm{NaHCO}_{3}$ was dissolved in the medium, with the gas mixture flowing, for buffering it at $\mathrm{pH} 6.8$.

Then the medium was divided in culture bottles $(50 \mathrm{~mL}$ each) and covered with rubber caps and aluminum caps. Afterwards, the headspace of the culture bottles was flushed with $\mathrm{N}_{2}: \mathrm{CO}_{2}$ (80\%:20\%) gas mixture for removing the headspace air; the pressure was controlled using a manifold system connected to a vacuum and compressor systems. Finally, the medium was autoclaved $\left(121^{\circ} \mathrm{C}, 21 \mathrm{~min}\right)$.

Before inoculation with $10 \%$ of $G$. sulfurreducens, $5 \mathrm{~mL} \mathrm{~L}^{-1}$ of the trace vitamin solution was added to the culture bottles. The vitamin solution was prepared and stored as the others stock solutions and contains $4.00 \mathrm{mg} \mathrm{L}^{-1}$ biotin, $4.00 \mathrm{mg} \mathrm{L}^{-1}$ folic acid, $20.00 \mathrm{mg} \mathrm{L}^{-1}$ pyridoxine-HCl, $10.00 \mathrm{mg} \mathrm{L}^{-1}$ thiamine- $\mathrm{HCl} . \mathrm{H}_{2} \mathrm{O}, 10.00 \mathrm{mg} \mathrm{L}^{-1}$ riboflavin, $10.00 \mathrm{mg} \mathrm{L}^{-1}$ nicotinic acid, $10.00 \mathrm{mg} \mathrm{L}^{-1} \mathrm{D}$-Ca-pantothenate, $0.20 \mathrm{mg} \mathrm{L}^{-1}$ vitamin $\mathrm{B} 12, \quad 10.00 \mathrm{mg} \mathrm{L}^{-1} \mathrm{p}$-aminobenzoic acid, $10.00 \mathrm{mg} \mathrm{L}^{-1}$ lipoic acid. G. sulfurreducens is capable to oxidize different organic compounds like acetate, fumarate, or others carbon sources [57, 59,70]. Na-acetate and $\mathrm{Na}_{2}$ fumarate were also added. Na-acetate served as carbon source and electron donor and $\mathrm{Na}_{2}$-fumarate served as electron receptor $[60,61]$. The Na-acetate and $\mathrm{Na}_{2}$-fumarate were previously prepared, filtered with a sterilized filter $(0.22 \mu \mathrm{m})$ and stored at $4{ }^{\circ} \mathrm{C}$ in sterile conditions and were used as final concentration of $1.64 \mathrm{~g} \mathrm{~L}^{-1}$ and $8 \mathrm{~g} \mathrm{~L}^{-1}$ in the culture bottles, respectively.

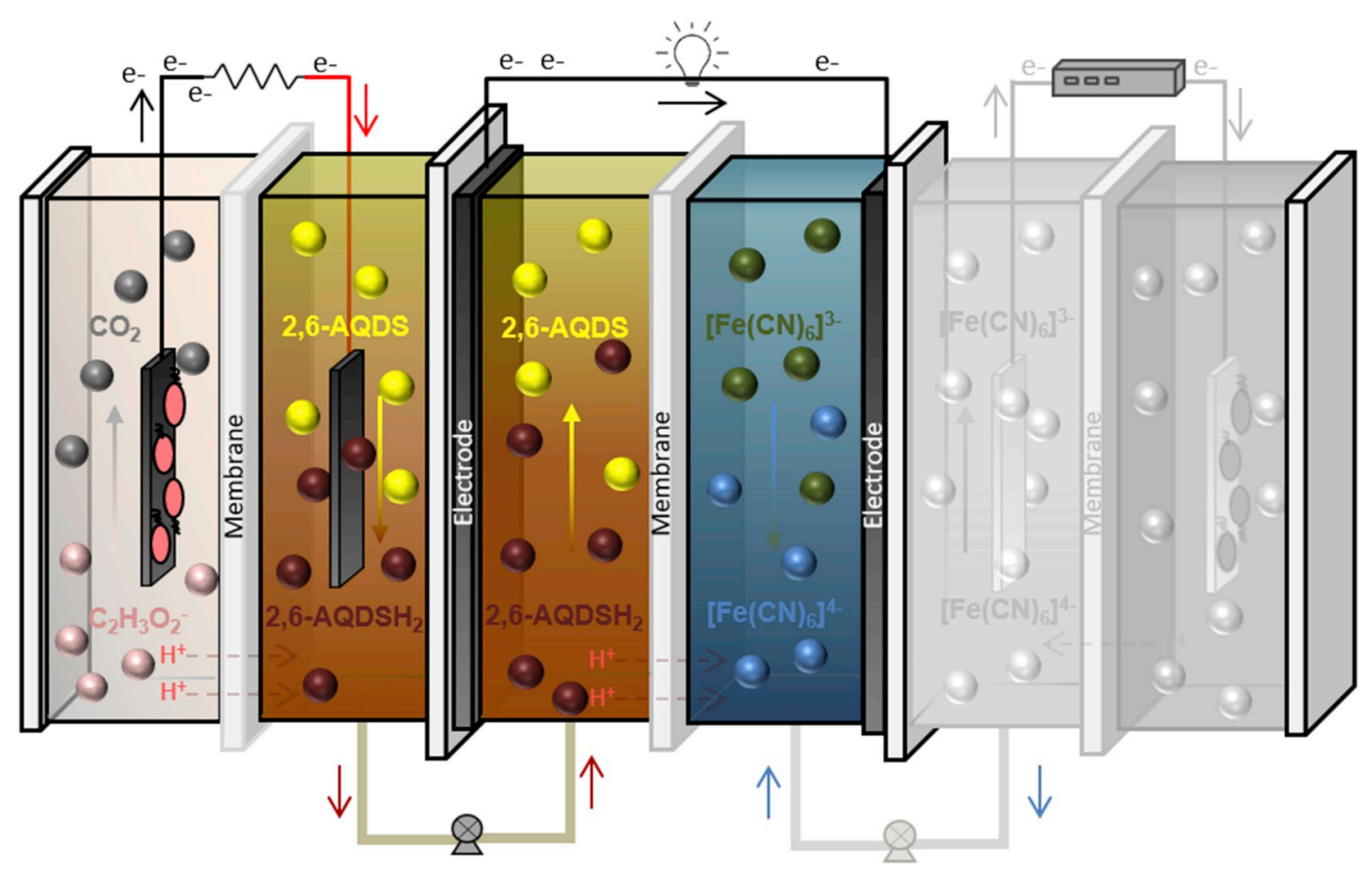

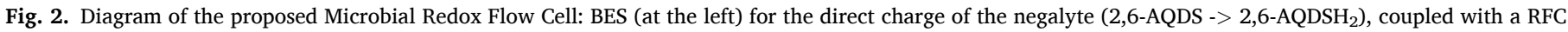
$\left(2,6-\mathrm{AQDS} \|\left[\mathrm{Fe}(\mathrm{CN})_{6}\right]^{4-}\right)$. On the right hand side, a second BES (in grey, not reported) is set for charging the posilyte of the RFC. 


\subsection{MFCs setup and experimental conditions}

MFCs made of transparent acrylic were used, as represented in Fig. 2. The anode and cathode chambers were built with a volume of $50 \mathrm{~cm}^{3}$ each. Between the chambers, a Nafion ${ }^{\mathrm{TM}} 117$ proton exchange membrane was tightened. The membrane was previously regenerated with $10 \% \mathrm{H}_{2} \mathrm{SO}_{4}$, during $3 \mathrm{~h}$ at $40{ }^{\circ} \mathrm{C}$ and rinsed several times with Milli-Q water. Two carbon felt electrodes $\left(0.1 \times 4 \mathrm{~cm}^{2}\right)$ were electrically connected to two electrical wires held using carbon cement (Leit-C, Sigma Aldrich). They were connected using a resistor (500 $\Omega$ ).

Anode and cathode containers were washed with chloramine and rinsed several times with Milli-Q water to remove sources of microbial contamination, and the MFCs were assembled in a laminar flux chamber. Geobacter medium and bacteria G. sulfurreducens (10\%) were introduced in the anode chamber using sterile syringes. Cathode chamber was filled with $20 \mathrm{mM}$ of anthraquinone-2,6-disulfonic acid disodium salt 97\% (2,6-AQDS) prepared in buffer solution (0.1 M sodium phosphate buffer solution, $\mathrm{pH}$ 7). The MFCs in the end was flushed with a gas mixture of $\mathrm{N}_{2}: \mathrm{CO}_{2}(80 \%: 20 \%)$ using sterile filters to guarantee anaerobic conditions.

Two MFC experiments were run. In both cases the anode chamber was stirred using a stirring plate and the MFC were kept at room temperature. In the first experiment (MFC A), the 2,6-AQDS reduction was identified by visual color change, as seen in previous report [71]. The MFC operated in three consecutive time series stages (series I, II, III) to assess the biofilm's capacity for bioelectricity production while observing the color change of the redox conversion (reduction of 2 , 6-AQDS). The 2,6-AQDS solution was refreshed when the color red was persistent for more than $24 \mathrm{~h}$ and the current density decreased. In MFC A experiment, Na-acetate $(20 \mathrm{mM})$ was added at the instant zero and every 3 days to minimize carbon source limitations, so that the maximum current densities could be reached.

In the second experiment (MFC B), two MFCs (MFC B1 and MFC B2) were operated in parallel as duplicates in order to estimate Coulombic efficiency of MFC operation and to quantify the 2,6-AQDSH ${ }_{2}$ concentrations in the end of the experiment.

UV-Vis spectrophotometry analyses were performed as follows: samples were taken from the anode chamber to evaluate the microbial growth by optical density at $600 \mathrm{~nm}\left(\mathrm{OD}_{600}\right)$ at the initial and at final time of the experiment and read in a spectrophotometer DR 2800 (Hach Lange, Düsseldorf, Germany). Acetate consumption over time was measured to calculate Coulombic efficiency of the system. The concentration of acetate present in the anode chamber of MFCs was analyzed by High-Performance Liquid Chromatography (Jasco, Japan) using a UV detector $(210 \mathrm{~nm})$ and a Chrompack column $\left(6.5 \times 30 \mathrm{~mm}^{2}\right)$ at $60^{\circ} \mathrm{C}$, where sulphuric acid $\left(0.5 \mathrm{~mol} \mathrm{~L}^{-1}\right)$ as mobile phase was used at a flow rate of $0.6 \mathrm{~mL} \mathrm{~min}^{-1}$.

The electrochemical fuel (microbially-charged electrochemical fuel) reduced in the cathode chamber was collected at the end of the trials, and immediately introduced in a serum vial previously washed with $\mathrm{N}_{2}$ (100\%) and moved to an anaerobic chamber for UV-Vis Spectrophotometry analyses, as described in the UV-Vis Spectrophotometry section. All experiments were performed sheltered to minimize light induced redox reactions. In the end of all assays, the polarization and power curves were performed.

\subsection{MFCs electrochemical characterization}

The open circuit potential (OCP) of the MFCs was measured using a multimeter (HP Hewlett Packard 34401A multimeter). It should be emphasized that no bias potential was applied during these experiments. The potential difference between the anode and cathode was recorded using an Ecograph T data logger (RSG 30 Endress + Hauser B.V., Naarden). The polarization and power curves were performed using a series of resistances ranging between $31 \mathrm{k} \Omega$ and $10 \Omega$ [47]. The maximum power density is calculated as indicated in literature [37].
The Coulombic efficiency $\left(\eta_{\mathrm{cb}}, \%\right)$ is the recovery of electrons, defined as the fraction (or percentage) of electrons recovered as current versus the organic matter depletion; the oxidation of the substrate occurs with the removal of electrons, with the moles defined of each substrate based on writing out a half reaction [65]. The Coulombic efficiency is described by equation (1):

$\eta_{c b}=\frac{M \int_{0}^{t} I d t}{F z v_{A n} \Delta C}$

where the integral of the current $(I)$ over a period of time $(\mathrm{d} t)$ is determined; $M$ is the molecular mass of the substrate $\left(\mathrm{g} \mathrm{L}^{-1}\right)$ (Na-acetate), $F$ is the Faraday's constant, $V_{A n}$ is the volume of liquid in the anode compartment (L), $z$ is the number of electrons exchanged per mol of substrate and $\Delta C$ is the change of substrate concentration $\left(\mathrm{g} \mathrm{L}^{-1}\right)$ over the batch cycle.

\subsection{Cyclic Voltammetry}

Cyclic Voltammetry (CV) of culture medium of G. sulfurreducens was performed using MFC as electrochemical cell. A three electrode configuration was settled, with $\mathrm{Ag} / \mathrm{AgCl}(3 \mathrm{M})$ as reference electrode, carbon felt electrode as working electrode, and $0.1 \mathrm{M} \mathrm{KCl}$ in the opposite chamber with an electrode of carbon felt as counter electrode. A Nafion $^{\mathrm{TM}} 117$ proton exchange membrane was used and a scan rate of $20 \mathrm{mV} \mathrm{s}^{-1}$ was executed.

The 2,6-AQDS ( $1 \mathrm{mM}$ in $0.1 \mathrm{M}$ sodium phosphate buffer solution, $\mathrm{pH}$ 7) and the $\mathrm{K}_{3} \mathrm{Fe}(\mathrm{CN})_{6}(1 \mathrm{mM}$ in $0.1 \mathrm{M}$ sodium phosphate buffer solution, $\mathrm{pH} 7$ ) were also studied by CV using an electrochemical cell in a three electrode configuration with $\mathrm{Ag} / \mathrm{AgCl}(3 \mathrm{M})$ as reference electrode, glassy carbon (working electrode) and platinum/titanium (counterelectrode). All electrochemical experiments were made with a potentiostat (Ec-Lab Potentiostat, BioLogic Scientific Instruments) and all solutions were deaerated with $\mathrm{N}_{2}(100 \%)$, prior to experiments. All results were converted to normal hydrogen electrode reference (NHE).

\subsection{UV-Vis Spectrophotometry}

UV-Vis Spectrophotometry was used to estimate the concentration of 2,6-AQDS (oxidized form) present in the cathode chamber of MFCs. The 2,6-AQDS concentration is normally quantified within 250-350 nm wavelength [66,72,73]; in this work it was quantified at $330 \mathrm{~nm}$. A standard curve was obtained by measuring the absorbance of reference solutions with concentrations ranging between $0.10 \mathrm{mM}$ and $0.75 \mathrm{mM}$ (obtained by dilution of a stock solution of $1 \mathrm{mM} 2,6-\mathrm{AQDS}$ ). All the samples were analyzed inside an anaerobic chamber using a GENESYS ${ }^{\mathrm{TM}}$ 20 Visible Spectrophotometer using a $10 \mathrm{~mm}$ quartz cell. The concentration of 2,6-AQDS was quantified at the end of the experiments with MFCs and the concentration of the microbially-charged electrochemical fuel was estimated. The dilutions required for the quantification were performed inside an anaerobic chamber.

\section{7. $R F C$ experimental setup and operation}

A RFC with $16 \mathrm{~cm}^{2}$ active membrane area was assembled in a flowthrough configuration. Nafion NM 117 proton exchange membrane was used for separating the anode from the cathode. The carbon felt GFD4.6 EA from SGL was thermal treated at $400^{\circ} \mathrm{C}$ for $6 \mathrm{~h}$ based on previous literature $[74,75]$. The bipolar plates were made of graphite (RCGBPP01) from RoyCarbon, China. Contacts to the current collectors were made with nickel-coated copper plates. Charging/discharging studies were carried out using a ZENNIUM (Zahner Elektrik, Germany) electrochemical workstation in a two-electrode galvanostatic configuration. On the anode side, the microbially-charged electrochemical fuel $\left(2,6-\mathrm{AQDSH}_{2}\right)$ was placed in a hotplate stirrer that was used at $50{ }^{\circ} \mathrm{C}$ 
with $1100 \mathrm{rpm}$; on the cathode side, no temperature or agitation was applied. The supporting electrolyte was $0.1 \mathrm{M}$ sodium phosphate buffer solution, $\mathrm{pH}$ 7. Watson Marlow $323 \mathrm{pump}$ was used to maintain an electrolyte flow rate of $20 \mathrm{~mL} \mathrm{~min}^{-1}$ during the cycling measurements. Both reservoirs were argon purged before and during test to minimize oxidation of species. Cycling measurements were conducted at default current densities of $37.5 \mathrm{~A} \mathrm{~cm}^{-2}$. The Coulombic, potential and energy efficiencies of the RFC were determined as described in the literature [76].

\section{Results and discussion}

\subsection{Electric current generation during quinone reduction - first experiment in MFC A}

The MFCs were assembled to study the bioelectrochemical conversion of 2,6-AQDS ( $20 \mathrm{mM} 2,6$-AQDS) to the reduced form (2,6-AQDSH ${ }_{2}$ ) using G. sulfurreducens as electroactive bacteria. Fig. 3 shows the MFC assembled and the color change from yellow (2,6-AQDS) at the beginning to dark red (microbially-charged electrochemical fuel, 2,6$\mathrm{AQDSH}_{2}$ ) at the end.

The current density over time of the first MFC A experiment (external resistance load of $500 \Omega$ ) is plotted in Fig. 4; after 2,6-AQDS being reduced, the solution was removed from the MFC using a syringe and a fresh solution of 2,6-AQDS reintroduced for running the next series.

At $\mathrm{pH} 7$, the redox reaction for all MFCs are $[44,77]$ :

$$
\begin{array}{ll}
\mathrm{C}_{2} \mathrm{H}_{3} \mathrm{O}_{2}^{-}+2 \mathrm{H}_{2} \mathrm{O} \rightleftharpoons 2 \mathrm{CO}_{2}+7 \mathrm{H}^{+}+8 \mathrm{e}^{-} & E_{\text {oxd }}^{0}=0.28 \mathrm{~V}_{\mathrm{NHE}} \\
\mathrm{C}_{14} \mathrm{H}_{6} \mathrm{Na}_{2} \mathrm{O}_{8} \mathrm{~S}_{2}+2 \mathrm{e}^{-}+2 \mathrm{H}^{+} \rightleftharpoons \mathrm{C}_{14} \mathrm{H}_{8} \mathrm{Na}_{2} \mathrm{O}_{8} \mathrm{~S}_{2} & E_{\mathrm{red}}^{0}=-0.184 \mathrm{~V}_{\mathrm{NHE}}
\end{array}
$$

Na-acetate was added during the electrochemical conversion of the quinone in order to avoid carbon source limitations and promote the maximum current densities. Fresh 2,6-AQDS was added at the beginning of each time series in order to take advantage of the anodic biofilm established at the surface of the electrode and to promote a low activation potential needed for the bioelectrochemical conversion of the fuel.

In the first day (series I), the observed lag phase (the adaptation phase necessary for the G. sulfurreducens to grow as anode biofilm, [78]) was followed by an increase of the current density up to $520 \mathrm{~mA} \mathrm{~m}^{-2}$, obtained in the second day of operation $(38 \mathrm{~h})$. For series II and III, the respective maximum current densities were $450 \mathrm{mAm}^{-2}$ and $414 \mathrm{~mA} \mathrm{~m}^{-2}$. The current density decreased after reaching the maximum as a result of the Na-acetate consumption and quinone reduction. The MFC current density decreased slowly over time (from series I to III) due to the increase of MFC internal resistance, which is normal in long operations due to membrane fouling and to changes in anode medium mineral composition [78].

To analyze the MFC A performance, polarization and power curves

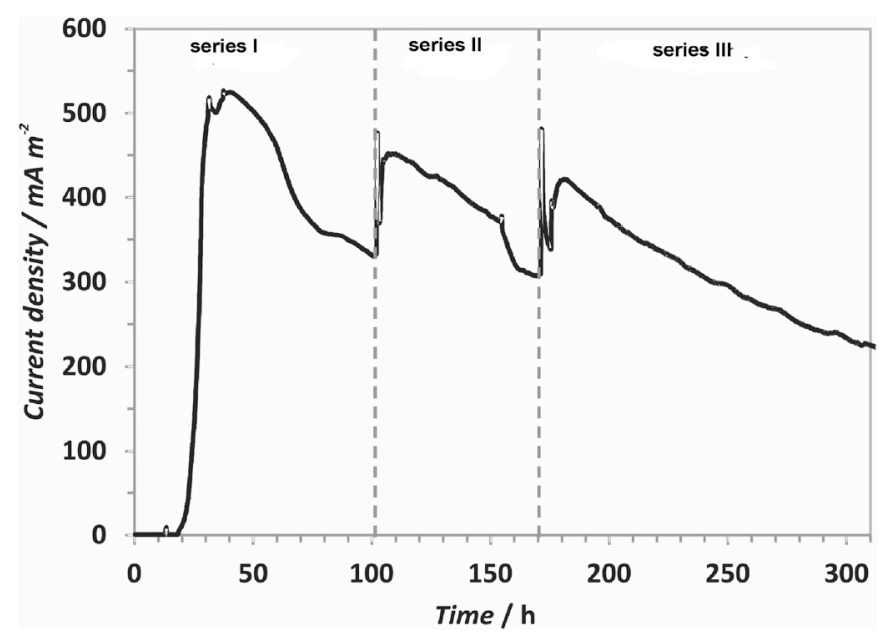

Fig. 4. Current density $\left(\mathrm{mA} \mathrm{m}^{-2}\right.$ ) over time (h) for the bioelectrochemical reduction of 2,6-AQDS in MFC A operated in series; (——) corresponds to the removal of the exhausted 2,6-AQDS.

were determined at the end of each series (Fig. 5). The OCP was determined at the stable phase of power generation for series I $(129 \mathrm{mV})$, series II $(207 \mathrm{mV})$ and series III (193 mV).

The power curves show that, for series I, the highest power density achieved was $15.4 \mathrm{~mW} \mathrm{~m}^{-2}$ with a current density of $358 \mathrm{~mA} \mathrm{~m}^{-2}$; for series II the maximum power density of $32.6 \mathrm{~mW} \mathrm{~m}^{-2}$ was achieved, with a current density of $521 \mathrm{~mA} \mathrm{~m}^{-2}$; and for series III the maximum power density was $1.98 \mathrm{~mW} \mathrm{~m}^{-2}$ with a current density of $84.2 \mathrm{~mA} \mathrm{~m}^{-2}$.

The polarization curves show an initial phase where activation losses predominate, followed by a region dominated by ohmic losses; the internal resistances were estimated from the slope of the curve in this region [37]. Internal resistance of $219 \Omega$ for series I, $325 \Omega$ for series II and $648 \Omega$ for series III were estimated, showing an ohmic resistance increase. From Fig. 5 it can be concluded that the power efficiency was higher for series II.

\subsection{Electric current generation during quinone reduction - second experiment in MFCs B1 and B2}

The current density over time for an external resistance load of $500 \Omega$ in the MFCs B1 and B2 are shown in Fig. 6.

The maximum current density was reached at $200 \mathrm{~h}\left(285.5 \mathrm{~mA} \mathrm{~m}^{-2}\right)$ for MFC B1 and at $27 \mathrm{~h}\left(422 \mathrm{~mA} \mathrm{~m}^{-2}\right)$ for MFC B2. The characteristic color change suggesting the reduction of 2,6-AQDS (from a yellow to a dark red color) was observed in both devices. The current generation achieved during the conversion of organic molecules (acetate, glucose, etc.) in batch or fed-batch MFC systems is typically low [51], as a consequence of the bacterial growth and other competitive processes [37]. Here, the current density produced in MFC B2 was faster than in

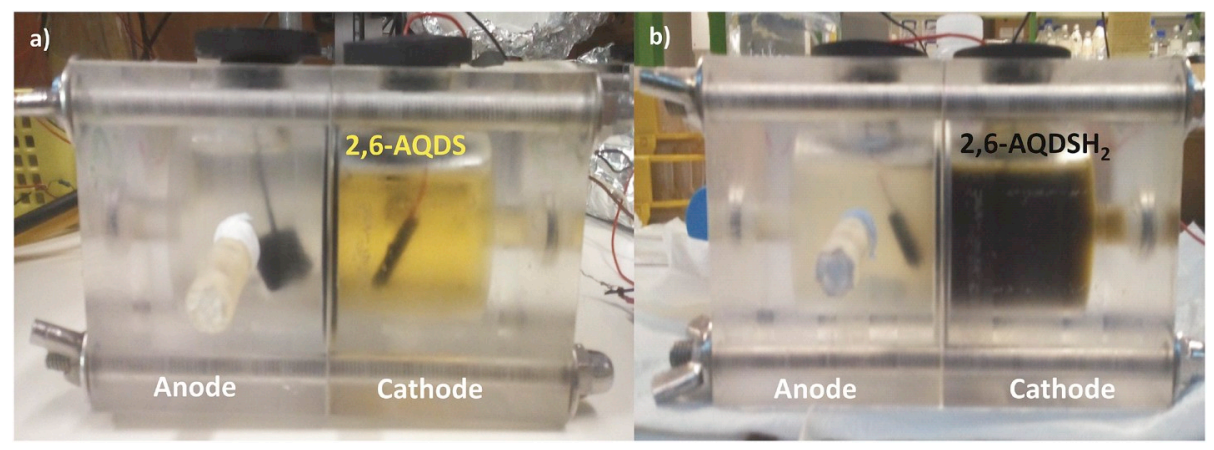

Fig. 3. MFC with G. sulfurreducens (anode) and 2,6-AQDS (cathode) at instant zero (a) and at the end of the assay (b). 
a)

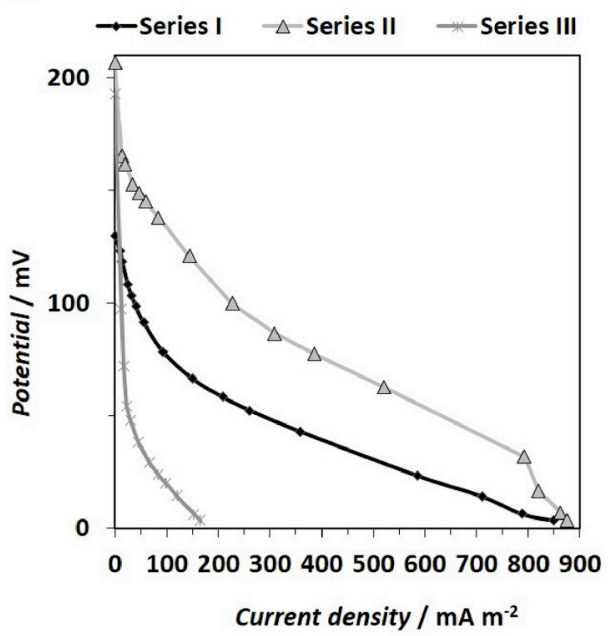

b)

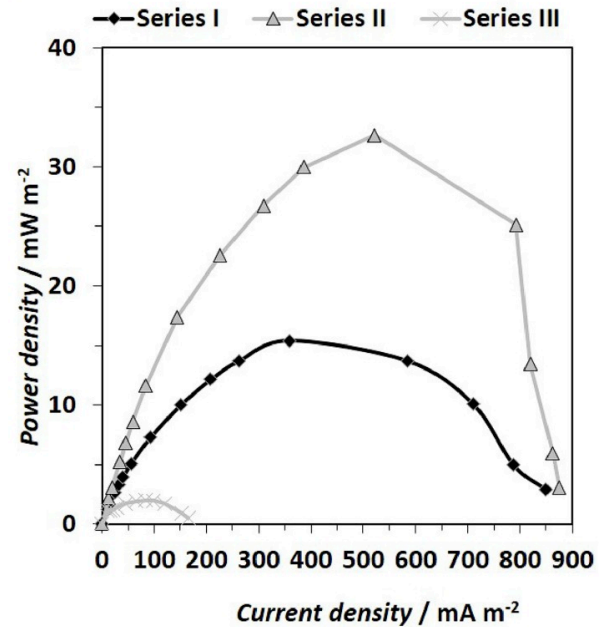

Fig. 5. Polarization (a) and power curves (b) obtained for MFC A operated in series.

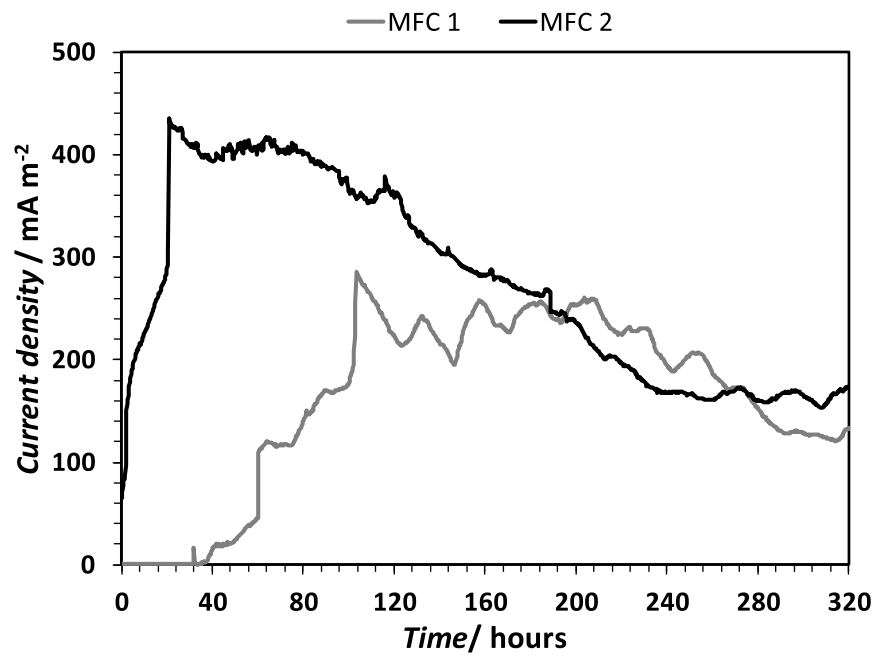

Fig. 6. Current density $\left(\mathrm{mA} \cdot \mathrm{m}^{-2}\right)$ over time $(\mathrm{h})$ for the bioelectrochemical reduction of 2,6-AQDS in MFCs (MFC B1 and MFC B2).

MFC B1, and the highest current density was observed in the initial hours. As the current generation is directly proportional to the anode biofilm growth [59], the result obtained was expected as the measured optical density $\left(\mathrm{OD}_{600}\right)$ in MFC B1 increased from 0.093 to 0.287 whereas in MFC $\mathrm{B} 2$ the initial cell concentration was higher and $\mathrm{OD}_{600}$ increased from 0.358 to 0.423 . Notwithstanding the slower start-up of MFC B1, both cells evolved to reach similar current densities, evidencing that a lower inoculum concentration do not impair the establishment of a proper electroactive biofilm.

The polarization and the power curves were determined at the end of the MFCB1 and MFCB2 (Fig. S1). The OCP of $65 \mathrm{mV}$ was recorded at the stable phase of the power generation; internal resistances as low as $0.38 \Omega$ and $0.23 \Omega$ were estimated for MFC B1 and MFC B2, respectively, from the slop of the polarization curve (Fig. S1a). These values were smaller than the ones observed in the experiment with MFC A operated in series. The highest power density obtained for MFC B1 was $3 \mathrm{~mW} \mathrm{~m}^{-2}$ $\left(100 \mathrm{~mA} \mathrm{~m}^{-2}\right.$ ) and for MFC B2 was $4 \mathrm{~mW} \mathrm{~m}^{-2}\left(138 \mathrm{~mA} \mathrm{~m}^{-2}\right.$ ) (Fig. S1b).

The Coulombic efficiency was estimated in MFC B1 and MFC B2, resulting in $20.0 \%$ and $20.2 \%$, for the $320 \mathrm{~h}$, respectively. The Coulombic efficiency obtained was smaller than the one obtained in a previous work with $G$. sulfurreducens and Na-acetate as carbon source [62]. The lower value of Coulombic efficiency in the current work could be related to the smaller fraction of electrons from the reaction that were transferred to the anode [62,79]. The smaller area of the electrodes and volume of the reactor may have influenced this result. An improvement in the Coulombic efficiency could be reached with optimization procedures [80,81]. But for the proof-of-concept a model organism, G. sulfurreducens was seen as the best electroactive bacteria [82], and acetate as a simple carbon source.

BESs have been largely used to generate and store energy in the form of hydrogen with the consumption of organic compounds, however the application of potential is required [83]. One of the biggest achievements in the BES under assessment in the present work (in both experiments) is that no bias potential was applied. This proves that electroactive bacteria in a MFC are able to promote the conversion of the redox pair 2,6-AQDS/2,6-AQDSH $\mathrm{A}_{2}$, as a microbially-charged electrochemical fuel. Optimization procedures, new materials or physical designs reactors could help reduce the period of time for this oxidations reactions in MFCs [32,80,81].

After $320 \mathrm{~h}$ the microbially-charged electrochemical fuel was removed for analysis. The final 2,6-AQDSH $\mathrm{A}_{2}$ concentration was calculated as the difference between the initial $(20 \mathrm{mM})$ and the final concentrations of 2,6-AQDS (oxidized form) (15.61 mM at MFC B1 and $16.7 \mathrm{mM}$ at MFC B2). The reduction of 2,6-AQDS to 2,6-AQDSH $\mathrm{A}_{2}$ was also confirmed by the visual color change [71] from yellow to dark red, as seen in Fig. 3 for MFC A.

\subsection{RFCs results}

Cyclic Voltammetry of $1 \mathrm{mM}$ 2,6-AQDS (electrochemically reduced) and $1 \mathrm{mM}\left[\mathrm{Fe}(\mathrm{CN})_{6}\right]^{3-}$ at $20 \mathrm{mV} \mathrm{s}^{-1}$ were performed to confirm the RFC potential using the selected redox pair. It was confirmed that the redox pairs are electrochemically reversible and the redox potentials are as expected from previous reports [84,85] (Fig. 7).

The microbially-charged electrochemical fuel $\left(2,6-\mathrm{AQDSH}_{2}\right)$ from MFC B2 and MFC A operated in series (series II) was used in a RFC as negalyte, with potassium hexacyanoferrate (III) as posilyte. The discharging redox reactions are:

$$
\mathrm{C}_{14} \mathrm{H}_{8} \mathrm{Na}_{2} \mathrm{O}_{8} \mathrm{~S}_{2} \rightleftharpoons \mathrm{C}_{14} \mathrm{H}_{6} \mathrm{Na}_{2} \mathrm{O}_{8} \mathrm{~S}_{2}+2 \mathrm{H}^{+}+2 \mathrm{e}^{-} \quad E_{\text {oxd }}^{0}=0.184 \mathrm{~V}_{\mathrm{NHE}}
$$

$\left[\mathrm{Fe}(\mathrm{CN})_{6}\right]^{3-}+\mathrm{e}^{-} \rightleftharpoons\left[\mathrm{Fe}(\mathrm{CN})_{6}\right]^{4-} \quad E_{\mathrm{red}}^{0}=0.436 \mathrm{~V}_{\mathrm{NHE}}$

The charging-discharging curves obtained with microbially-charged electrochemical fuel from MFC B2, the Coulombic, potential and energy efficiencies and energy capacity for $3.75 \mathrm{~mA} \mathrm{~cm}^{-2}$ of current density 


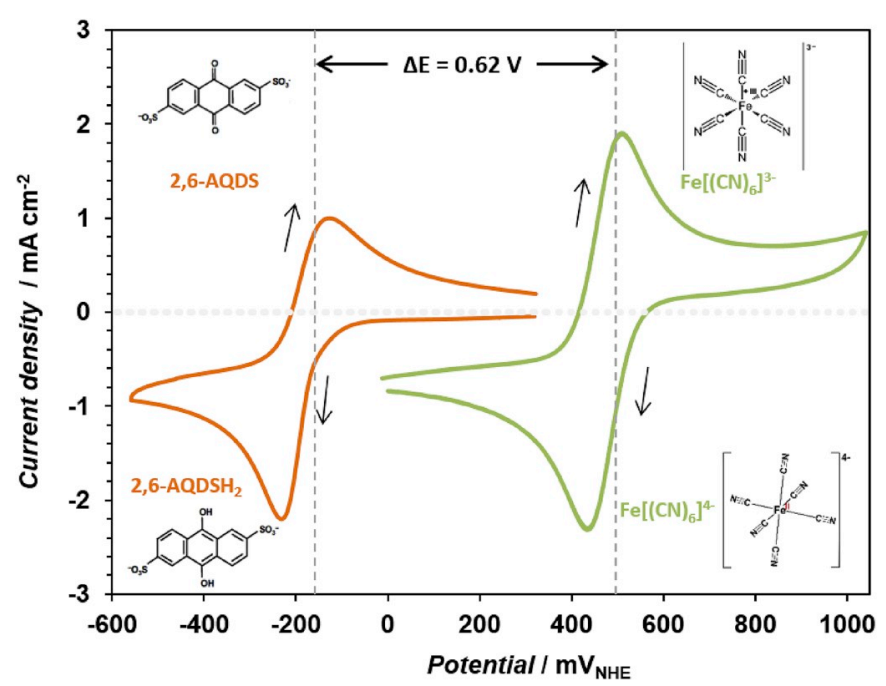

Fig. 7. Cyclic voltammograms at $20 \mathrm{mVs}^{-1}$ for $1 \mathrm{mM}$ 2,6-AQDS (orange color, left) and $1 \mathrm{mM}$ potassium hexacyanoferrate (III) (green color, right), at $\mathrm{pH} 7$. (For interpretation of the references to color in this figure legend, the reader is referred to the Web version of this article.)

\section{(Fig. 8).}

The Coulombic efficiency for the 10 cycles was $c a .100 \%$ and the potential efficiency was $c a$. 85\%; the energy efficiency was $c a .85 \%$ (Fig. 8b). These results were achieved by starting at the discharged mode, with a microbially-charged electrochemical fuel from MFC B2. The same discharge test with the RFC for the microbially-charged electrochemical fuel obtained in the MFC A series II was performed, however problems with assembling the cell (e.g. precipitation of the quinone in negalyte electrode) were assisted (data not show). The results from the Fig. 8 that used 2,6-AQDSH$H_{2}$ as negalytes from a MFC operated in batch cycles (Fig. 8) suggested that a complete batch cycle to convert the microbially-charged electrochemical fuel is more efficient for the reduction of the quinone, and this is implicit in the results of the battery discharge curves. These charge-discharge curves show that microbiallycharged electrochemical fuel detain the redox potential and the chemical properties of a redox pair of a RFC, achieving high Coulombic and energy efficiencies. Coulombic and energies efficiencies achieved in Fig. 8, are in the same range of RFC efficiencies with 2,6-AQDS used as negalyte [25]. In this proof-of-concept, the RFCs were operated with at current density of $3.75 \mathrm{~mA} \mathrm{~cm}^{-2}$, whereas high-performance RFCs reach $0.1-0.5 \mathrm{~A} \mathrm{~cm}^{-2} @ 80 \%$ of round-trip-efficiency [86].

Even though the RFC did not reach the cell potentials seen in some aqueous organic RFC, it was still possible to reach energy efficiencies superior to $c a$. $80 \%$, even using a lower concentration of quinone $(0.02 \mathrm{M})$ than the one usually reported in literature (a maximum solubility of $0.5 \mathrm{M}$ and cycling performance at $0.2 \mathrm{M}$ concentration of 2,6 AQDS [29]). The concentration of $20 \mathrm{mM}$ 2,6-AQDS was selected for the MRFC, since its solubility at room temperature in water is $\mathrm{H}_{2} \mathrm{O}<3 \%$, solubility $\left(10 \mathrm{mg} \mathrm{mL}^{-1} \mathrm{H}_{2} \mathrm{O}\right)$. The use of new redox pairs, displaying higher energy density, such as 2,7-AQDS [87] and POM [88], should now be initiated; this last system allows energy densities up to $150 \mathrm{Wh}$ $\mathrm{L}^{-1}$.

\section{Conclusion}

MFCs were used to reduce 2,6-AQDS to 2,6- $\mathrm{AQDSH}_{2}$ to be used as a microbially-charged electrochemical fuel in a Redox Flow Cell. The reduction of 2,6-AQDS was confirmed by UV-Vis Spectrophotometry and $\mathrm{CV}$, obtaining a maximum of $15 \mathrm{mM}$ of microbially-charged electrochemical fuel. The 2,6-AQDS was bio-reduced to 2,6-AQDSH $\mathrm{H}_{2}$ with a maximum current density in the range of $400-500 \mathrm{~mA} \mathrm{~m}^{-2}$ and a maximum power density of $c a .33 \mathrm{~mW} \mathrm{~m}^{-2}$ in MFC operated in series.
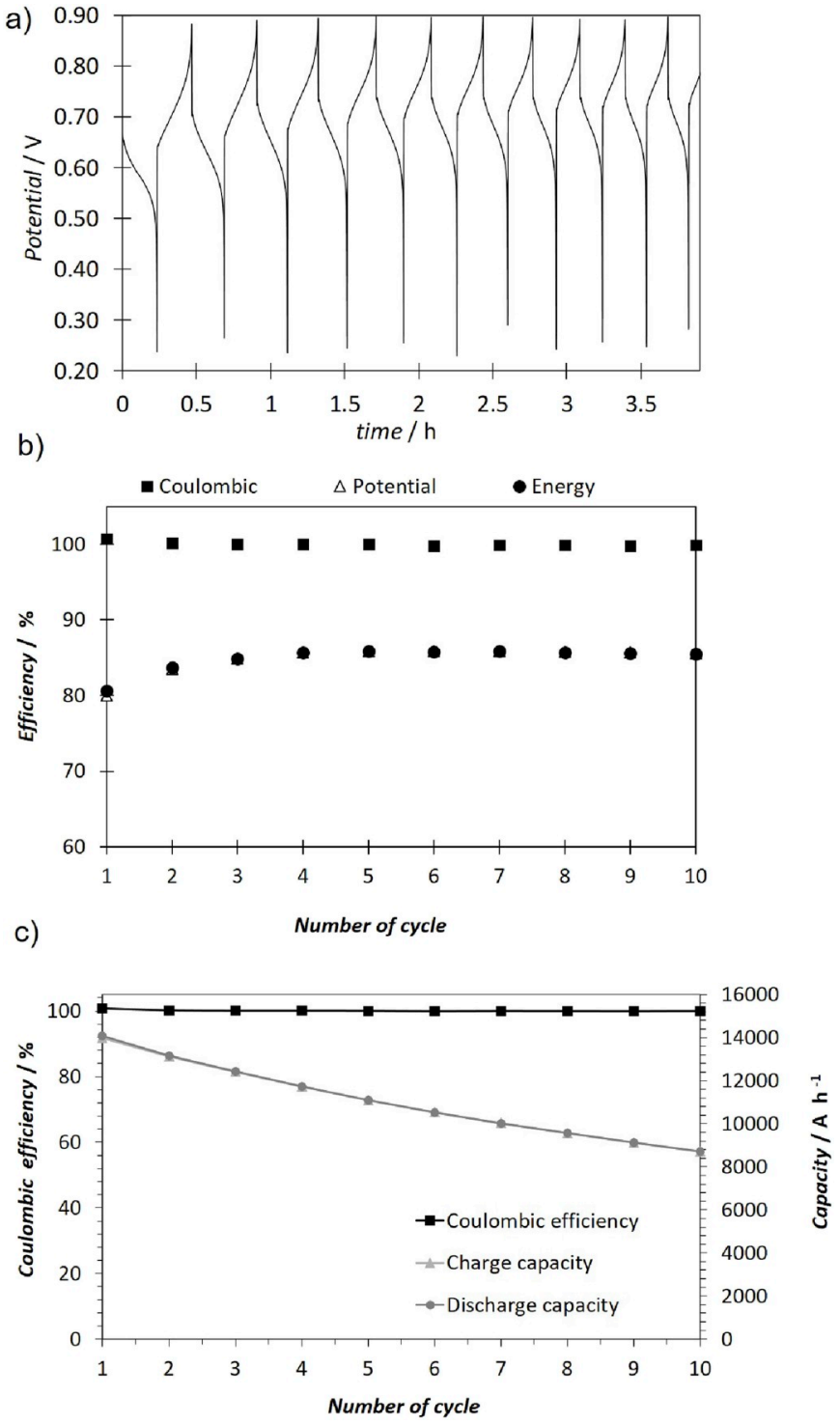

Fig. 8. Charge-discharge curves versus time (a), Coulombic (black square), potential (black triangle) and energy efficiencies (black circle) versus the cycle number (b) in the RFC at current density of $3.75 \mathrm{~mA} \mathrm{~cm}^{-2}$ and (c) capacity for 10 cycles for RFC with 2,6-AQDSH ${ }_{2}$ from the MFC B2.

It was demonstrated that the microbially-charged electrochemical fuel developed in the MFC can be used as negative redox pair of the 2,6AQDS $\|\left[\mathrm{Fe}(\mathrm{CN})_{6}\right]^{4-}$ in a RFC, promoting energy efficiencies $c a$. $80 \%$. The research team is now developing the bio-charging of the positive redox pair, $\left[\mathrm{Fe}(\mathrm{CN})_{6}\right]^{4-}$, aiming at the development of a feasible technology for converting bio-energy into storable electrochemical energy-that we designated Microbial Redox Flow Cell. Microbially-charged electrochemical fuels using electroactive bacteria is advantageous compared with converting bio-energy into hydrogen; actually, a microbially redox flow cell can be charged unbiased while microbially water splitting is a biased process [89].

\section{Declaration of competing interest}

There are no conflicts of interest to declare.

\section{Acknowledgements}

M.S.S. Santos is grateful to Portuguese Foundation for Science and 
Technology for her PhD fellow (reference: SFRH/BD/104087/2014). J. Azevedo is grateful to the FCT for is Postdoctoral Grant (Reference: SFRH/BPD/116648/2016) and for funding (CEECIND/03937/2017). Ricardo Monteiro was also grateful for their Postdoctoral Grant by FCT (Reference: SFRH/BPD/112900/2015). The authors would like to acknowledge to the FCT under the scope of the strategic funding of UID/ BIO/04469 unit and COMPETE 2020 (POCI-01-0145-FEDER-006684) and BioTecNorte operation (NORTE-01-0145-FEDER-000004) funded by the European Regional Development Fund (ERDF), under the scope of Norte2020 - Programa Operacional Regional do Norte. The authors also acknowledge the Projects: i) POCI-01-0145-FEDER-006939 (LEPABE Laboratory for Process Engineering, Environment, Biotechnology and Energy - UID/EQU/00511/2013), funded by the ERDF, through COMPETE2020 - Programa Operacional Competitividade e Internacionalização (POCI) and by nationals funds through FCT, ii) by the Project SunStorage - Harvesting and storage of solar energy", with reference POCI-01-0145-FEDER-016387, funded by ERDF, through COMPETE 2020 -POCI), and by national funds, through FCT; (iii) Project PTDC/EQU-EQU/30510/2017 - POCI-01-0145-FEDER-030510 - Sunflow "Solar energy storage into redox flow batteries" funded by FEDER funds through COMPETE2020 - Programa Operacional Competitividade e Internacionalização (POCI) and by national funds (PIDDAC) through FCT/MCTES and iV) NORTE-01-0145-FEDER-000005 LEPABE-2-ECO-INNOVATION, supported by North Portugal Regional Operational Programme (Norte 2020), under the Portugal 2020 Partnership Agreement, through the ERDF. The authors are indebted with all the colleagues who assisted in the laboratory work, in particular to Dr. Sónia Barbosa for help with microbial fuel cell operation.

\section{Appendix A. Supplementary data}

Supplementary data to this article can be found online at https://doi. org/10.1016/j.jpowsour.2019.227307.

\section{References}

[1] A.Z. Weber, M.M. Mench, J.P. Meyers, P.N. Ross, J.T. Gostick, Q. Liu, Redox flow batteries: a review, J. Appl. Electrochem. 41 (2011) 1137-1164, https://doi.org/ 10.1007/s10800-011-0348-2.

[2] J. Noack, N. Roznyatovskaya, T. Herr, P. Fischer, The chemistry of redox-flow batteries, Angew. Chem. Int. Ed. 54 (2015) 9776-9809, https://doi.org/10.1002/ anie.201410823.

[3] Y. Zhu, F. Yang, Z. Niu, H. Wu, Y. He, H. Zhu, J. Ye, Y. Zhao, X. Zhang, Enhanced cyclability of organic redox flow batteries enabled by an artificial bipolar molecule in neutral aqueous electrolyte, J. Power Sources 417 (2019) 83-89, https://doi. org/10.1016/j.jpowsour.2019.02.021.

[4] Jason Deign, Study: flow batteries beat lithium ion - energy Storage Report (accessed March 19, 2018), http://energystoragereport. info/study-flow-batteries-beat-lithium-ion/\#sthash.raSuCrMH.OIZ1fCJu.dpbs, 2017.

[5] O. Schmidt, A. Hawkes, A. Gambhir, I. Staffell, The future cost of electrical energy storage based on experience rates, Nat. Energy 2 (2017) 17110, https://doi.org/ 10.1038/nenergy.2017.110.

[6] L. Li, S. Kim, W. Wang, M. Vijayakumar, Z. Nie, B. Chen, J. Zhang, G. Xia, J. Hu, G. Graff, J. Liu, Z. Yang, A stable vanadium redox-flow battery with high energy density for large-scale energy storage, Adv. Energy Mater. 1 (2011) 394-400, https://doi.org/10.1002/aenm.201100008.

[7] C. Choi, S. Kim, R. Kim, Y. Choi, S. Kim, H. young Jung, J.H. Yang, H.T. Kim, A review of vanadium electrolytes for vanadium redox flow batteries, Renew. Sustain. Energy Rev. 69 (2017) 263-274, https://doi.org/10.1016/j. rser.2016.11.188.

[8] C. Bae, E.P.L. Roberts, M.H. Chakrabarti, M. Saleem, A008. All-chromium redox flow battery for renewable energy storage, Int. J. Green Energy 8 (2011) 248-264, https://doi.org/10.1080/15435075.2010.549598.

[9] K. Gong, F. Xu, J.B. Grunewald, X. Ma, Y. Zhao, S. Gu, Y. Yan, All-soluble all-iron aqueous redox-flow battery, ACS Energy Lett. (2016) 89-93, https://doi.org/ 10.1021/acsenergylett.6b00049.

[10] B. Li, Z. Nie, M. Vijayakumar, G. Li, J. Liu, V. Sprenkle, W. Wang, Ambipolar zincpolyiodide electrolyte for a high-energy density aqueous redox flow battery, Nat. Commun. 6 (2015) 6303, https://doi.org/10.1038/ncomms7303.

[11] F. Pan, Q. Wang, Redox species of redox flow batteries: a review, Molecules 20 (2015) 20499-20517, https://doi.org/10.3390/molecules201119711.

[12] W. Wang, V. Sprenkle, Energy storage: redox flow batteries go organic, Nat. Chem. 8 (2016) 204-206, https://doi.org/10.1038/nchem.2466.
[13] K. Wedege, E. Dražević, D. Konya, A. Bentien, Organic redox species in aqueous flow batteries: redox potentials, chemical stability and solubility, Sci. Rep. 6 (2016) 39101, https://doi.org/10.1038/srep39101.

[14] E.J. Son, J.H. Kim, K. Kim, C.B. Park, Quinone and its derivatives for energy harvesting and storage materials, J. Mater. Chem. A. 4 (2016) 11179-11202, https://doi.org/10.1039/C6TA03123D.

[15] B. Li, J. Liu, Progress and directions in low-cost redox-flow batteries for large-scale energy storage, Natl. Sci. Rev. 4 (2017) 91-105, https://doi.org/10.1093/nsr/ nww098.

[16] R.S. Kim, T.D. Chung, The electrochemical reaction mechanism and applications of quinones, Bull. Korean Chem. Soc. 35 (2014) 3143-3155, https://doi.org/ 10.5012/bkcs.2014.35.11.3143.

[17] B. Huskinson, M.P. Marshak, M.R. Gerhardt, M.J. Aziz, Cycling of a quinonebromide flow battery for large-scale electrochemical energy storage, ECS Trans. 61 (2014) 27-30, https://doi.org/10.1149/06137.0027ecst.

[18] K. Lin, Q. Chen, M.R. Gerhardt, L. Tong, S.B. Kim, L. Eisenach, A.W. Valle, D. Hardee, R.G. Gordon, M.J. Aziz, M.P. Marshak, Alkaline quinone flow battery, Science 349 (2015) 1529-1532, https://doi.org/10.1126/science.aab3033 (80-.).

[19] X. Liang, S. Peng, Y. Lei, C. Gao, N. Wang, S. Liu, D. Fang, Effect of l-glutamic acid on the positive electrolyte for all-vanadium redox flow battery, Electrochim. Acta 95 (2013) 80-86, https://doi.org/10.1016/j.electacta.2013.01.138.

[20] Z. He, G. Jin, C. Gao, Y. Chen, H. Han, J. Liu, A new redox flow battery of high energy density with V/Mn hybrid redox couples, J. Renew. Sustain. Energy 6 (2014), 053124, https://doi.org/10.1063/1.4898368.

[21] Y. Lu, J.B. Goodenough, Rechargeable alkali-ion cathode-flow battery, J. Mater. Chem. 21 (2011) 10113, https://doi.org/10.1039/c0jm04222f.

[22] Y. Zhao, Y. Ding, Y. Li, L. Peng, H.R. Byon, J.B. Goodenough, G. Yu, A chemistry and material perspective on lithium redox flow batteries towards high-density electrical energy storage, Chem. Soc. Rev. 44 (2015) 7968-7996, https://doi.org/ $10.1039 / \mathrm{c} 5 \mathrm{cs} 00289 \mathrm{c}$

[23] T. Liu, X. Wei, Z. Nie, V. Sprenkle, W. Wang, A total organic aqueous redox flow battery employing a low cost and sustainable methyl viologen anolyte and 4-HOTEMPO catholyte, Adv. Energy Mater. 6 (2016) 1501449, https://doi.org/ 10.1002/aenm.201501449.

[24] B. Huskinson, M.P. Marshak, C. Suh, S. Er, M.R. Gerhardt, C.J. Galvin, X. Chen, A. Aspuru-Guzik, R.G. Gordon, M.J. Aziz, A metal-free organic-inorganic aqueous flow battery, Nature 505 (2014) 195-198, https://doi.org/10.1038/nature12909.

[25] B. Yang, L. Hoober-Burkhardt, S. Krishnamoorthy, A. Murali, G.K.S. Prakash, S. R. Narayanan, High-Performance aqueous organic flow battery with quinone-based redox couples at both electrodes, J. Electrochem. Soc. 163 (2016) 1442-1449, https://doi.org/10.1149/2.1371607jes.

[26] T. Davies, J. Tummino, High-performance Vanadium Redox Flow Bateries with Graphite Felt Electrodes, Multidisciplinary Digital Publishing Institute, 2018, https://doi.org/10.3390/c4010008.

[27] A. Orita, M.G. Verde, M. Sakai, Y.S. Meng, A biomimetic redox flow battery based on flavin mononucleotide, Nat. Commun. 7 (2016) 13230, https://doi.org/ $10.1038 /$ ncomms13230.

[28] M. Skyllas-Kazacos, C. Menictas, T. Lim, Redox flow batteries for medium- to largescale energy storage, in: Ziad Melhem (Ed.), Electr. Transm. Distrib. Storage Syst, Elsevier, 2013, pp. 398-441, https://doi.org/10.1533/9780857097378.3.398.

[29] B. Yang, L. Hoober-Burkhardt, F. Wang, G.K. Surya Prakash, S.R. Narayanan, An inexpensive aqueous flow battery for large-scale electrical energy storage based on water-soluble organic redox couples, J. Electrochem. Soc. 161 (2014) A1371-A1380, https://doi.org/10.1149/2.1001409jes.

[30] M.R. Gerhardt, L. Tong, R. Gómez-Bombarelli, Q. Chen, M.P. Marshak, C.J. Galvin, A. Aspuru-Guzik, R.G. Gordon, M.J. Aziz, Anthraquinone derivatives in aqueous flow batteries, Adv. Energy Mater. 7 (2017) 1601488, https://doi.org/10.1002/ aenm. 201601488.

[31] J. Azevedo, T. Seipp, J. Burfeind, C. Sousa, A. Bentien, J.P. Araújo, A. Mendes, Unbiased solar energy storage: photoelectrochemical redox flow battery, Nano Energy 22 (2016) 396-405, https://doi.org/10.1016/j.nanoen.2016.02.029.

[32] K. Wedege, J. Azevedo, A. Khataee, A. Bentien, A. Mendes, Direct solar charging of an organic-inorganic, stable, and aqueous alkaline redox flow battery with a hematite photoanode, Angew. Chem. Int. Ed. 55 (2016) 7142-7147, https://doi. org/10.1002/anie.201602451.

[33] X. Li, Modeling and simulation study of a metal free organic-inorganic aqueous flow battery with flow through electrode, Electrochim. Acta 170 (2015) 98-109, https://doi.org/10.1016/j.electacta.2015.04.075.

[34] B.E. Logan, Microbial Fuel Cells, Wiley-Interscience, Hoboken, NJ, USA, 2008, https://doi.org/10.1002/9780470258590.fmatter.

[35] K. Scott, E.H. Yu, Microbial Electrochemical and Fuel Cells: Fundamentals and Applications, 2016, https://doi.org/10.1016/B978-1-78242-375-1.00012-5.

[36] D. Pant, A. Singh, G. Van Bogaert, S. Irving Olsen, P. Singh Nigam, L. Diels, K. Vanbroekhoven, Bioelectrochemical systems (BES) for sustainable energy production and product recovery from organic wastes and industrial wastewaters, RSC Adv. 2 (2012) 1248, https://doi.org/10.1039/c1ra00839k.

[37] B.E. Logan, B. Hamelers, R. Rozendal, U. Schröder, J. Keller, S. Freguia, P. Aelterman, W. Verstraete, K. Rabaey, Microbial fuel cells: methodology and technology, Environ. Sci. Technol. 40 (2006) 5181-5192, https://doi.org/ 10.1021/es0605016.

[38] M. Balat, Microbial fuel cells as an alternative energy option, Energy Sources Part A Recover, Util. Environ. Eff. 32 (2010) 26-35, https://doi.org/10.1080/ 15567030802466045.

[39] S. Ishii, S. Suzuki, T.M. Norden-Krichmar, A. Wu, Y. Yamanaka, K.H. Nealson, $\mathrm{O}$. Bretschger, Identifying the microbial communities and operational conditions 
for optimized wastewater treatment in microbial fuel cells, Water Res. 47 (2013) 7120-7130, https://doi.org/10.1016/J.WATRES.2013.07.048.

[40] E. Blásquez, D. Grabiel, J.A. Baeza, A. Guisasola, Treatment of high-strength sulfate wastewater using an autotrophic biocathode in view of elemental sulfur recovery, Water Res. 105 (2016) 395-405, https://doi.org/10.1016/J. WATRES.2016.09.014.

[41] B.E. Logan, D. Call, S. Cheng, H.V.M. Hamelers, T.H.J.A. Sleutels, A.W. Jeremiasse, R.A. Rozendal, Microbial electrolysis cells for high yield hydrogen gas production from organic matter, Environ. Sci. Technol. 42 (2008) 8630-8640, https://doi.org/ 10.1021/es801553z.

[42] M. Kitching, R. Butler, E. Marsili, Microbial bioelectrosynthesis of hydrogen: current challenges and scale-up, Enzym. Microb. Technol. 96 (2017) 1-13, https:// doi.org/10.1016/j.enzmictec.2016.09.002.

[43] P.F. Beese-Vasbender, J.P. Grote, J. Garrelfs, M. Stratmann, K.J.J. Mayrhofer, Selective microbial electrosynthesis of methane by a pure culture of a marine lithoautotrophic archaeon, Bioelectrochemistry 102 (2015) 50-55, https://doi. org/10.1016/j.bioelechem.2014.11.004.

[44] K. Rabaey, R.A. Rozendal, Microbial electrosynthesis - revisiting the electrical route for microbial production, Nat. Rev. Microbiol. 8 (2010) 706-716, https:// doi.org/10.1038/nrmicro2422.

[45] O. Choi, T. Kim, H.M. Woo, Y. Um, Electricity-driven metabolic shift through direct electron uptake by electroactive heterotroph Clostridium pasteurianum, Sci. Rep. 4 (2015) 6961, https://doi.org/10.1038/srep06961.

[46] Y. Kim, B.E. Logan, Microbial desalination cells for energy production and desalination, Desalination 308 (2013) 122-130, https://doi.org/10.1016/j desal.2012.07.022.

[47] L. Peixoto, A.L. Rodrigues, G. Martins, A. Nicolau, A.G. Brito, M.M. Silva, P. Parpot, R. Nogueira, A flat microbial fuel cell for decentralized wastewater valorization: process performance and optimization potential, Environ. Technol. 34 (2013) 1947-1956, https://doi.org/10.1080/09593330.2013.827223.

[48] E. Comission, Bioelectrochemical systems : wastewater treatment , bioenergy and valuable chemicals delivered by bacteria, accessed August 28, 2017, http://ec.eur opa.eu/environment/integration/research/newsalert/pdf/FB5_en.pdf, 2013.

[49] J.M. Morris, S. Jin, Feasibility of using microbial fuel cell technology for bioremediation of hydrocarbons in groundwater, J. Environ. Sci. Health. A Tox. Hazard. Subst. Environ. Eng. 43 (2008) 18-23, https://doi.org/10.1080/ 10934520701750389.

[50] Z. Ge, L. Wu, F. Zhang, Z. He, Energy extraction from a large-scale microbial fuel cell system treating municipal wastewater, J. Power Sources 297 (2015) 260-264, https://doi.org/10.1016/j.jpowsour.2015.07.105.

[51] C. Santoro, C. Arbizzani, B. Erable, I. Ieropoulos, Microbial fuel cells: from fundamentals to applications. A review, J. Power Sources 356 (2017) 225-244, https://doi.org/10.1016/j.jpowsour.2017.03.109.

[52] F. Harnisch, Bioelectrorefeneries: Joining the Forces of Microbiology and Electrochemistry for Production of Chemicals and Fuels, vol. 6, ISMET, Lisbon, 2017, p. 7. https://www.is-met.org/sites/default/files/AbstractsBook_ISMET6.pdf.

[53] T. Kim, J. Yeo, Y. Yang, S. Kang, Y. Paek, J.K. Kwon, J.K. Jang, Boosting voltage without electrochemical degradation using energy-harvesting circuits and power management system-coupled multiple microbial fuel cells, J. Power Sources 410-411 (2019) 171-178, https://doi.org/10.1016/j.jpowsour.2018.11.010.

[54] T.C. Pannell, R.K. Goud, D.J. Schell, A.P. Borole, Effect of fed-batch vs. continuous mode of operation on microbial fuel cell performance treating biorefinery wastewater, Biochem. Eng. J. 116 (2016) 85-94, https://doi.org/10.1016/j. bej.2016.04.029.

[55] S.G. Barbosa, L. Peixoto, A. Ter Heijne, P. Kuntke, M.M. Alves, M.A. Pereira, Investigating bacterial community changes and organic substrate degradation in microbial fuel cells operating on real human urine, Environ. Sci. Water Res. Technol. 3 (2017) 897-904, https://doi.org/10.1039/C7EW00087A.

[56] S.G. Barbosa, L. Peixoto, O.S.G.P. Soares, M.F.R. Pereira, A. Ter Heijne, P. Kuntke, M.M. Alves, M.A. Pereira, Influence of carbon anode properties on performance and microbiome of Microbial Electrolysis Cells operated on urine, Electrochim. Acta 267 (2018) 122-132, https://doi.org/10.1016/j.electacta.2018.02.083.

[57] L. Peixoto, R. Nogueira, A. Brito, C. Póvoa, P. Kroff, P. Parpot, Electroactivity of Geobacter sulfurreducens evaluated by cyclic voltammetry, in: II Int. Conf. Environ. Ind. Appl. Microbiol. (BioMicroWorld 2007), Ind. Appl. Microbiol. (BioMicroWorld 2007), 2007, p. 176

[58] C. Koch, A. Kuchenbuch, J. Kretzschmar, H. Wedwitschka, J. Liebetrau, S. Müller, F. Harnisch, Coupling electric energy and biogas production in anaerobic digesters - impacts on the microbiome, RSC Adv. 5 (2015) 31329-31340, https://doi.org/ 10.1039/C5RA03496E.

[59] G. Reguera, K.P. Nevin, J.S. Nicoll, S.F. Covalla, T.L. Woodard, D.R. Lovley, Biofilm and nanowire production leads to increased current in Geobacter sulfurreducens fuel cells, Appl, Environ. Microbiol. 72 (2006) 7345-7348, https://doi.org/10.1128/ AEM.01444-06.

[60] K.P. Nevin, H. Richter, S.F. Covalla, J.P. Johnson, T.L. Woodard, A.L. Orloff, H. Jia M. Zhang, D.R. Lovley, Power output and columbic efficiencies from biofilms of Geobacter sulfurreducens comparable to mixed community microbial fuel cells, Environ. Microbiol. 10 (2008) 2505-2514, https://doi.org/10.1111/j.14622920.2008.01675.x.

[61] M.S. Kim, Y.J. Lee, Optimization of culture conditions and electricity generation using Geobacter sulfurreducens in a dual-chambered microbial fuel-cell, Int. J. Hydrogen Energy 35 (2010) 13028-13034, https://doi.org/10.1016/j. ijhydene.2010.04.061.

[62] A.M. Speers, G. Reguera, Electron donors supporting growth and electroactivity of Geobacter sulfurreducens anode biofilms, Appl. Environ. Microbiol. 78 (2012) 437-444, https://doi.org/10.1128/AEM.06782-11.
[63] M.-S. Kim, J. Cha, D.-H. Kim, Enhancing factors of electricity generation in a microbial fuel cell using Geobacter sulfurreducens, J. Microbiol. Biotechnol. 22 (2012) 1395-1400, https://doi.org/10.4014/jmb.1204.04010.

[64] G. Martins, L. Peixoto, D.C. Ribeiro, P. Parpot, A.G. Brito, R. Nogueira, Towards implementation of a benthic microbial fuel cell in lake Furnas (Azores): phylogenetic affiliation and electrochemical activity of sediment bacteria, Bioelectrochemistry 78 (2010) 67-71, https://doi.org/10.1016/j. bioelechem.2009.07.003.

[65] B.E. Logan, Microbial Fuel Cells, John Wiley \& Sons, Inc., Hoboken, NJ, USA, 2007, https://doi.org/10.1002/9780470258590.

[66] G. Nöll, G. Hauska, P. Hegemann, K. Lanzl, T. Nçll, M. Von Sanden-flohe, B. Dick, C.W.V. Gmbh, C. Kgaa, T. Nöll, M. von Sanden-Flohe, B. Dick, Redox properties of LOV domains: chemical versus photochemical reduction, and influence on the photocycle, Chembiochem 2007 (8) (2007) 2256-2264, https://doi.org/10.1002/ cbic.200700304.

[67] B.R. Ringeisen, E. Henderson, P.K. Wu, J. Pietron, R. Ray, B. Little, J.C. Biffinger, J. M. Jones-Meehan, High power density from a miniature microbial fuel cell using Shewanella oneidensis DSP10, Environ. Sci. Technol. 40 (2006) 2629-2634, https:// doi.org/10.1021/es052254w.

[68] L. Zeng, X. Li, S. Fan, M. Zhang, Z. Yin, M. Tadé, S. Liu, Photo-driven bioelectrochemical photocathode with polydopamine-coated $\mathrm{TiO}_{2}$ nanotubes for self-sustaining $\mathrm{MoS}_{2}$ synthesis to facilitate hydrogen evolution, J. Power Sources 413 (2019) 310-317, https://doi.org/10.1016/j.jpowsour.2018.12.054.

[69] M.S.S. Santos, L. Peixoto, C. Dias-Ferreira, A. Mendes, M.M. Alves, Microbially charged redox flow batteries for bioenergy storage, in: R.N. Krishnaraj, R.K. Sani (Eds.), Bioelectrochemical Interface Eng, Wiley, 2019, ISBN 978-1-119-53854-7, p. 251.

[70] D. Sun, J. Chen, H. Huang, W. Liu, Y. Ye, S. Cheng, The effect of biofilm thickness on electrochemical activity of Geobacter sulfurreducens, Int. J. Hydrogen Energy (2016) 2-7, https://doi.org/10.1016/j.ijhydene.2016.04.163.

[71] A. Cadena, A.-C. Texier, I. González, F.J. Cervantes, J. Gómez, Qualitative and quantitative determination of a humic model compound in microbial cultures by cyclic voltammetry, Environ. Technol. 28 (2007) 1035-1044, https://doi.org/ 10.1080/09593332808618862.

[72] C. Liu, J.M. Zachara, N.S. Foster, J. Strickland, Kinetics of reductive dissolution of hematite by bioreduced anthraquinone-2,6-disulfonate, Environ. Sci. Technol. 41 (2007) 7730-7735, https://doi.org/10.1021/es070768k

[73] C. yuan Wu, L. Zhuang, S. gui Zhou, Y. Yuan, T. Yuan, F. bai Li, Humic substancemediated reduction of iron(III) oxides and degradation of 2,4-D by an alkaliphilic bacterium, Corynebacterium humireducens MFC-5, Microb. Biotechnol. 6 (2013) 141-149, https://doi.org/10.1111/1751-7915.12003.

[74] R. Monteiro, J. Leirós, M. Boaventura, A. Mendes, Insights into all-vanadium redox flow battery: a case study on components and operational conditions, Electrochim. Acta 267 (2018) 80-93, https://doi.org/10.1016/j.electacta.2018.02.054.

[75] B. Sun, M. Skyllas-Kazacos, Modification of graphite electrode materials for vanadium redox flow battery application-I. Thermal treatment, Electrochim. Acta 37 (1992) 1253-1260, https://doi.org/10.1016/0013-4686(92)85064-R.

[76] C.P. de León, A. Frías-Ferrer, J. González-García, D.A. Szánto, F.C. Walsh, Redox flow cells for energy conversion, J. Power Sources 160 (2006) 716-732, https:// doi.org/10.1016/j.jpowsour.2006.02.095.

[77] S. Orsetti, C. Laskov, S.B. Haderlein, Electron transfer between iron minerals and quinones estimating the reduction potential of the $\mathrm{Fe}(\mathrm{II})$-goethite surface from AQDS Speciation, Environ. Sci. Technol. 47 (2013) 1-6, https://doi.org/10.1021/ es403658g.

[78] M.D. Rolfe, C.J. Rice, S. Lucchini, C. Pin, A. Thompson, A.D.S. Cameron, M. Alston, M.F. Stringer, R.P. Betts, J. Baranyi, M.W. Peck, J.C.D. Hinton, Lag phase is a distinct growth phase that prepares bacteria for exponential growth and involves transient metal accumulation, J. Bacteriol. 194 (2012) 686-701, https://doi.org/ 10.1128/JB.06112-11.

[79] N. Degrenne, F. Buret, B. Allard, P. Bevilacqua, Electrical energy generation from a large number of microbial fuel cells operating at maximum power point electrical load, J. Power Sources 205 (2012) 188-193, https://doi.org/10.1016/j. jpowsour.2012.01.082.

[80] P. Pandey, V.N. Shinde, R.L. Deopurkar, S.P. Kale, S.A. Patil, D. Pant, Recent advances in the use of different substrates in microbial fuel cells toward wastewater treatment and simultaneous energy recovery, Appl. Energy 168 (2016) 706-723, https://doi.org/10.1016/J.APENERGY.2016.01.056.

[81] S. Chen, S.A. Patil, R.K. Brown, U. Schröder, Strategies for optimizing the power output of microbial fuel cells: transitioning from fundamental studies to practical implementation, Appl. Energy 233-234 (2019) 15-28, https://doi.org/10.1016/j. apenergy.2018.10.015.

[82] D.R. Lovley, T. Ueki, T. Zhang, N.S. Malvankar, P.M. Shrestha, K.A. Flanagan, M. Aklujkar, J.E. Butler, L. Giloteaux, A.-E. Rotaru, D.E. Holmes, A.E. Franks, R. Orellana, C. Risso, K.P. Nevin, Geobacter: the microbe electric's physiology, ecology, and practical applications, Adv. Microb. Physiol. (2011) 1-100, https:// doi.org/10.1016/B978-0-12-387661-4.00004-5.

[83] F. Fischer, S. Mermoud, G. Diouf, C. Bastian, Bio-inspired chemical hydrogen storage and discharge as a source of electrical energy, J. Appl. Electrochem. 42 (2012) 419-425, https://doi.org/10.1007/s10800-012-0415-3.

[84] Y. Wu, F. Li, T. Liu, R. Han, X. Luo, pH dependence of quinone-mediated extracellular electron transfer in a bioelectrochemical system, Electrochim. Acta 213 (2016) 408-415, https://doi.org/10.1016/j.electacta.2016.07.122.

[85] M. Pandurangachar, B.E. Kumara Swamy, B.N. Chandrashekar, O. Gilbert, S. Reddy, B.S. Sherigara, Electrochemical investigations of potassium ferricyanide and dopamine by 1-butyl-4-methylpyridinium tetrafluoro borate modified carbon 
paste electrode: a cyclic voltammetric study, Int. J. Electrochem. Sci. 5 (2010) $1187-1202$.

[86] P. Leung, X. Li, C.P. de León, L. Berlouis, C.T.J. Low, F.C. Walsh, H. Chen, G. Cong, Y.C. Lu, P. Leung, X. Li, C.P. de León, L. Berlouis, C.T.J. Low, F.C. Walsh, Progress in redox flow batteries, remaining challenges and their applications in energy storage, RSC Adv. 2 (2012) 10125-10156, https://doi.org/10.1039/C2RA21342G.

[87] T.J. Carney, S.J. Collins, S.J. Moore, F.R. Brushett, Concentration-dependent dimerization of anthraquinone disulfonic acid and its impact on charge storage,
Chem. Mater. 29 (2017) 4801-4810, https://doi.org/10.1021/acs. chemmater.7b00616.

[88] J. Chen, M.D. Symes, L. Cronin, Highly reduced and protonated aqueous solutions of [P2W18O62]6- for on-demand hydrogen generation and energy storage, Nat. Chem. 10 (2018), https://doi.org/10.1038/s41557-018-0109-5.

[89] J.P. Torella, C.J. Gagliardi, J.S. Chen, D.K. Bediako, B. Colón, J.C. Way, P.A. Silver, D.G. Nocera, Efficient solar-to-fuels production from a hybrid microbial - watersplitting catalyst system, Proc. Natl. Acad. Sci. 112 (2015), https://doi.org/ 10.1073/pnas.1424872112. 